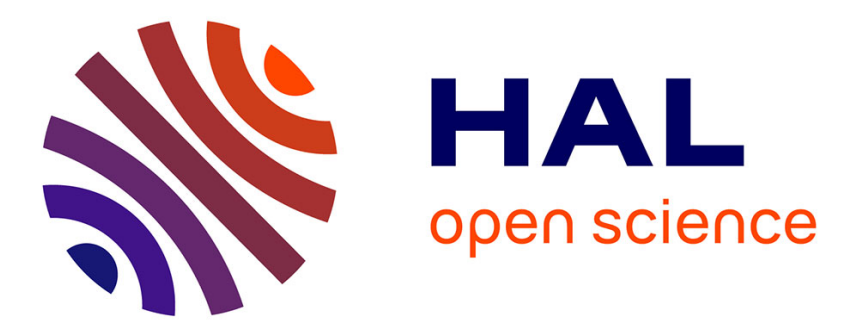

\title{
Recent advances on enzymatic glucose/oxygen and hydrogen/oxygen biofuel cells: Achievements and limitations
}

\author{
Serge Cosnier, Andrew J. Gross, Alan Le Goff, Michael Holzinger
}

\section{To cite this version:}

Serge Cosnier, Andrew J. Gross, Alan Le Goff, Michael Holzinger. Recent advances on enzymatic glucose/oxygen and hydrogen/oxygen biofuel cells: Achievements and limitations. Journal of Power Sources, 2016, 325, pp.252 - 263. 10.1016/j.jpowsour.2016.05.133 . hal-01644734

\author{
HAL Id: hal-01644734 \\ https://hal.science/hal-01644734
}

Submitted on 19 Nov 2020

HAL is a multi-disciplinary open access archive for the deposit and dissemination of scientific research documents, whether they are published or not. The documents may come from teaching and research institutions in France or abroad, or from public or private research centers.
L'archive ouverte pluridisciplinaire $\mathbf{H A L}$, est destinée au dépôt et à la diffusion de documents scientifiques de niveau recherche, publiés ou non, émanant des établissements d'enseignement et de recherche français ou étrangers, des laboratoires publics ou privés. 
See discussions, stats, and author profiles for this publication at: https://www.researchgate.net/publication/304105544

\section{Recent Advances on Enzymatic Glucose/Oxygen and Hydrogen/Oxygen Biofuel Cells: Achievements and Limitations}

Article in Journal of Power Sources · September 2016

DOI: 10.1016/j.jpowsour.2016.05.133

\section{CITATIONS}

94

4 authors:

Serge Cosnier

Université Grenoble Alpes

424 PUBLICATIONS 15,689 CITATIONS

SEE PROFILE

Alan Le Goff

University Joseph Fourier - Grenoble 1

103 PUBLICATIONS 3,935 CITATIONS

SEE PROFILE

Some of the authors of this publication are also working on these related projects:

Study on photo-electrochemical properties of metal-organic frameworks and their application View project

Project Dengue biosensor View project$$
\text { ngue biosensor View project }
$$

\section{READS}

682

Andrew J Gross

French National Centre for Scientific Research

47 PUBLICATIONS 525 CITATIONS

SEE PROFILE

Michael Holzinger

University Joseph Fourier - Grenoble 1

139 PUBLICATIONS 6,449 CITATIONS

SEE PROFILE 
Review article

\section{Recent advances on enzymatic glucose/oxygen and hydrogen/oxygen biofuel cells: Achievements and limitations

\author{
Serge Cosnier, ${ }^{*}$ Andrew Gross, Alan Le Goff, Michael Holzinger \\ Département de Chimie Moléculaire, UMR-5250, CNRS-Université de Grenoble Alpes, 38041 Grenoble, France
}

\section{A R T I C L E I N F O}

Article history:

Received 2 May 2016

Received in revised form 25 May 2016

Accepted 30 May 2016

Available online $\mathrm{xxx}$

\section{Keywords:}

Enzyme biofuel cell

Glucose

Implanted biofuel cell

Hydrogen biofuel cell

Enzyme wiring

Biocathode

\section{A B S T R A C T}

The possibility of producing electrical power from chemical energy with biological catalysts has induced the development of biofuel cells as viable energy sources for powering portable and implanted electronic devices. These power sources employ biocatalysts, called enzymes, which are highly specific and catalytic towards the oxidation of a biofuel and the reduction of oxygen or hydrogen peroxide. Enzymes, on one hand, are promising candidates to replace expensive noble metal-based catalysts in fuel cell research. On the other hand, they offer the exciting prospect of a new generation of fuel cells which harvest energy from body fluids. Biofuel cells which use glucose as a fuel are particularly interesting for generating electricity to power electronic devices inside a living body. Hydrogen consuming biofuel cells represent an emerging alternative to platinum catalysts due to comparable efficiencies and the capability to operate at lower temperatures. Currently, these technologies are not competitive with existing commercialised fuel cell devices due to limitations including insufficient power outputs and lifetimes. The advantages and challenges facing glucose biofuel cells for implantation and hydrogen biofuel cells will be summarised along with recent promising advances and the future prospects of these exotic energy-harvesting devices.

(C) 2016 Published by Elsevier Ltd.

\section{Introduction}

For four decades, the development of biointerfaces has been the subject of increasing research effort and now provides immense opportunities and major challenges for research fields such as health, environmental monitoring and energy. Concerning the energy field, the depletion of fossil fuels and the need for clean electricity production methods have led to the emergence of new sources of sustainable and renewable energy which do not emit $\mathrm{CO}_{2}$. Among these clean power generation strategies, biofuel cells that convert chemical energy into electrical energy by electro-enzymatic reactions have attracted considerable attention. Biofuel cells, constituting a subclass of fuel cells, mainly rely on redox enzymes which are very efficient and selective biocatalysts that can advantageously replace rare and expensive platinum-based catalysts in classic fuel cell devices.

Enzymes provide exceptional specificities towards their substrates, thus enabling the assembly of both the anode and cathode electrodes of a fuel cell without the need for membranes and noble metals. However, a constant challenge in enzymatic biofuel cell design is the so-called electrical "wiring" of biocatalysts with electrodes. Electrical wiring refers to the transfer of electrons involved in the power generating redox process to (at the cathode) and from (at the anode) the respective active sites of the biocatalysts [1]. In the ideal case, the external circuit directly exchanges the electrons with the enzymes leading to optimal cell voltages and maximising current

\footnotetext{
* Corresponding author.

Email address: serge.cosnier@univ-grenoble-alpes.fr (S. Cosnier)
}

outputs. Such direct electron transfer (DET), however, is unfortunately not achievable in all cases and strongly depends on the location and orientation of the active site inside the protein. When the catalytic centre is deeply embedded, for example, the distance to the electrode material is often too high for efficient electron transfer. In this case, small molecules having the appropriate redox potential and activity may be employed as electron shuttles, called mediators, to enhance electron transport. Despite an expected cell voltage loss and frequent stability issues for such mediated electron transfer (MET), electrical wiring of enzymes via MET is quantitative and frequently leads to higher catalytic currents than can be achieved by DET (Fig. 1).

Over the last two decades, steady improvements in biofuel cell design have led to devices with power outputs in the respectable $\mathrm{mW} \mathrm{cm}{ }^{-2}$ range and high energy densities in the $\mathrm{Wh} \mathrm{kg}^{-1}[2-6]$ compared to lithium ion batteries. Although the voltages of enzymatic biofuel cells are typically lower than those of commercial batteries $(1.5 \mathrm{~V}-3.6 \mathrm{~V})$, the energy density can reach up to almost $300 \mathrm{Wh} \mathrm{kg}^{-1}$ which, for example, compares to $150 \mathrm{Wh} \mathrm{kg}^{-1}$ for a rechargeable lithium ion battery or $160 \mathrm{Wh} \mathrm{kg}^{-1}$ for a $\mathrm{Li}-\mathrm{MnO}_{2}$ battery. Coupled with the ongoing development of ultra-low power microelectronic devices, tremendous interest in the use of biofuel cells as power sources for future practical applications can be assured.

A vast majority of biofuel cells generate electrical energy from the enzymatic degradation of glucose and oxygen, two substrates present in physiological fluids. Consequently, the major motivation for the development of enzymatic biofuel cells lies in their implantation in the human body as an autonomous power source of, in theory, unlim- 

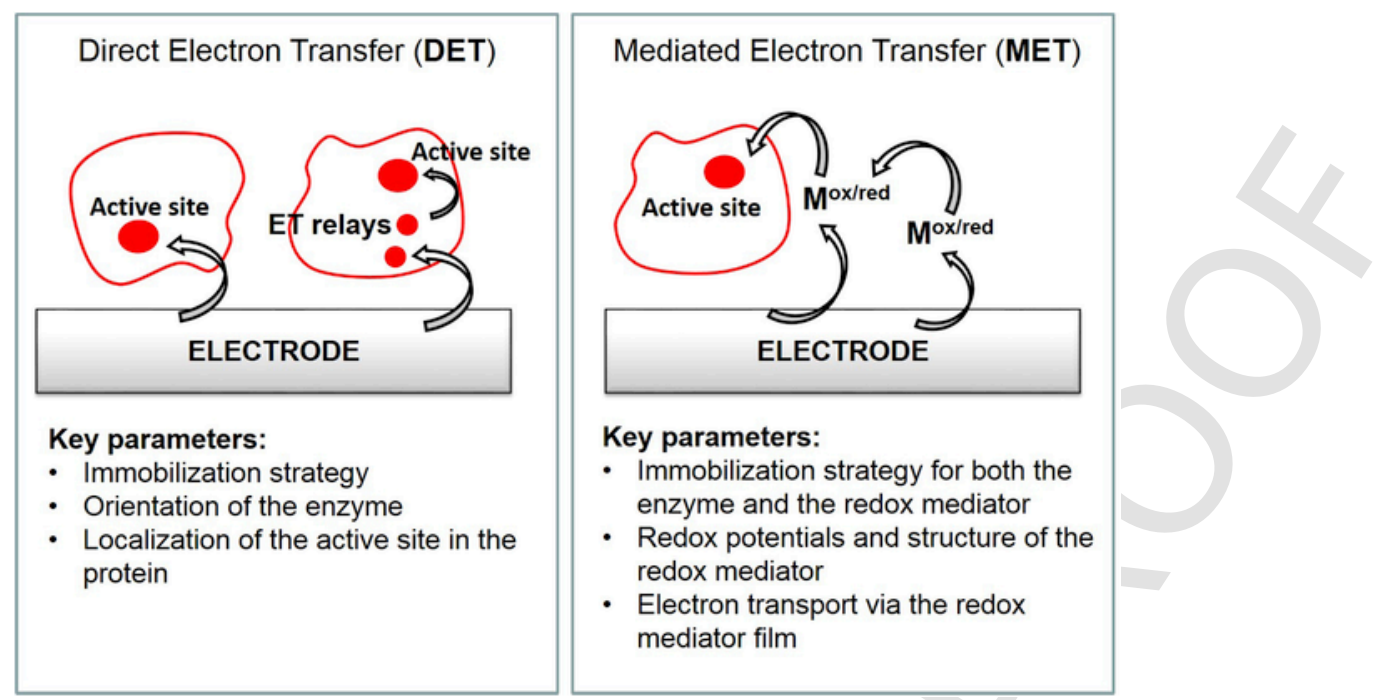

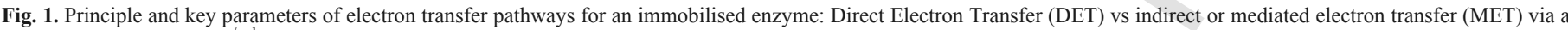
small redox mediator $\left(\mathrm{M}^{\text {ox/red }}\right)$.

ited energy, since the fuel glucose is steadily produced by metabolism [7-9]. Such biofuel cells thus constitute an attractive alternative to traditional fuel cells and primary batteries for powering implanted medical devices such as stimulating electrodes, pacemakers, pumps, metabolite sensors and bionic implants. The first biofuel cell entirely implanted in a mammal materialised the first step towards this goal in 2010 [10]. Since this pioneering work, special attention has been dedicated to the design and implementation of biofuel cell configurations implanted partially or completely into insects and animals. Recently it was demonstrated that the power output of a single implanted biofuel cell in a living organism was sufficient for powering small electronic devices such as pacemakers and a light-emitting diode [11]. The challenge now is to power a new generation of implanted medical devices capable of monitoring physiological processes and data transmission. Meeting this challenge will open up new prospects for scientists involved in fuel cell research and revolutionise medicine. However, it is commonly recognised that the development of such implantable power generators faces, up to now, insufficient power output in vivo and short lifetimes. Moreover, due to the small number of entirely implanted biofuel cells in animals, the impact of other technological barriers like sterilisation and biocompatible packaging have rarely been examined, despite being decisive factors for the future of these technologies.

Beside the use of glucose, which has the advantages of being present in human metabolism and being a safe and easy-to-handle energy compound, another vector of energy, hydrogen, has appeared more recently in the area of biofuel cells research. Biofuel cells, which exploit hydrogen will be dedicated to the powering of portable electronics or recharging of batteries in electronic equipment. Hydrogen is a vector of clean energy that can be stored as a gas under pressure. Thanks to the growing improvement in production, transport and storage of $\mathrm{H}_{2}$, and recent developments of highly efficient hydrogenases [12], a few examples of $\mathrm{H}_{2} / \mathrm{O}_{2}$ enzymatic fuel cells have been reported and presented as the most powerful biofuel cells for electricity production in the near future [13-15]. It should be noted that, in contrast to glucose, the small size of hydrogen and its gaseous nature may facilitate the combination of $\mathrm{O}_{2}$ and $\mathrm{H}_{2}$ breathing electrodes, and hence solve transport and diffusion problems in the development of biofuel cells.

Given the vast promise of $\mathrm{H}_{2} / \mathrm{O}_{2}$ biofuel cells, for electricity generation, and glucose $/ \mathrm{O}_{2}$ biofuel cells, for powering implanted medical devices, the aim of this review is to summarise significant recent advances in the field of biofuel cells and to identify the remaining technological bottlenecks to overcome before biofuel cells can be exploited for actual commercial applications.

\section{Implantable biofuel cells for in vivo applications}

Owing to the current problems of sterilisation, biocompatibility and short lifetimes of enzymatic biofuel cells for in vivo applications, the development of non-invasive and minimally-invasive biofuel cells has become increasingly attractive and represents an important step towards implantable biofuel cells [16]. Enzymatic biofuel cells which use metabolites such as glucose, lactate, pyruvate and ascorbate from human sweat, lachrymal fluids and saliva, have been developed and reviewed very recently [17]. Wang and coworkers pioneered the field of tattoo-based biofuel cells by utilising sweat lactate [18], while Shleev and coworkers have focused their efforts on the development of contact lens based biofuel cells to power glucose or lactate sensors [19]. In the same way, Minteer and coworkers recently reported an enzymatic fuel cell integrated into a contact lens [20]. Despite exciting advances towards flexible, resilient and wearable biofuel cells, and the fact that the concentration of oxygen is not a limiting parameter, major drawbacks remain concerning low power output, biocompatibility and device fabrication. Moreover, this approach is not a viable solution for powering medical devices implanted in the body since the skin provides a mechanical barrier to microorganisms (bacteria, viruses, protozoa or fungi) and should not be altered or crossed by cables. To eliminate contamination problems due to infectious microorganisms entering across an epithelium, the ideal route is full implantation of the biofuel cell inside the body.

Owing to the presence of glucose and oxygen in extracellular fluids (blood and interstitial fluid), the most exciting application for glucose $/ \mathrm{O}_{2}$ biofuel cells is their implantation in mammals to power medical devices. In 2010, Cosnier and coworkers conceived the first glucose biofuel cell setup based on free-standing enzymatic bioelectrodes which could be fully implanted in mammals, in collaboration with the clinicians group of Cinquin [10]. This biofuel cell integrated an original biocathode configuration based on an electrically wired polyphenol oxidase. The device exhibited maximum activity at $\mathrm{pH} 7$ and was compatible with physiological fluids. This enzyme had already been exploited by Cosnier and coworkers for the development 
of microbiosensors implanted in a rat brain [21]. Additionally, this type of enzyme electrode exhibited exceptional long-term storage stability with $80 \%$ of its initial sensitivity observed after one year storage in buffer [22]. This enzymatic fuel cell, fully implanted in the retroperitoneal space of a rat, demonstrated for the first time the possibility to harvest energy out of extracellular fluids of a mammal. Although the power output of $1.8 \mu \mathrm{W}$ for the biofuel cell remained stable during 11 days after implantation, the performance was far below the required levels to supply implanted devices. Following this breakthrough, and thanks to innovative advances in the design of nanostructured materials, various types of biofuel cells have been partially implanted in living organisms such as snails [23], insects [24-26], clams [27], lobsters [28], rats [29-31], and rabbits [32]. While electric power can be generated with glucose and oxygen in mammals, the disaccharide trehalose represents a fuel precursor present in insects which is enzymatically converted into glucose and can be exploited [25]. Many of these biofuel cells present significant progress in terms of enzyme wiring via carbon nanotubes. Nevertheless, the real power delivered in mammals by implanted biofuel cells remains very small $(0.0095-2.75 \mu \mathrm{W}$, depending on the electrode surface) and hence is inefficient for activating implanted biomedical devices.

Katz and coworkers have demonstrated that several clams or lobsters with implanted biofuel cells, connected in series or in parallel, can deliver enough power to supply low power electronics; namely, a watch, an electric motor, and a pacemaker [27,33]. However, they reported that biofuel cells cannot be connected in series in a single animal due to problems with tissue conductivity. This means that we must focus our efforts on increasing the power of the single biofuel cell itself. In that context, Cosnier and coworkers patented a novel approach for bioelectrode fabrication based on the compression of a mixture of carbon nanotubes and enzyme that provides, simultaneously, the immobilisation and electrical wiring of enzymes [2,34]. A biofuel cell based on glucose oxidase (GOx) and laccase delivered an impressive power output of $1.69 \mathrm{~mW}$ at open circuit voltage (OCV) and $1.3 \mathrm{~mW} \mathrm{~cm}^{-2}$ at $0.95 \mathrm{~V}$. Connecting two biofuel cells gave $3.25 \mathrm{~mW}$ at $1.8 \mathrm{~V}$. In 2013, this biofuel design was used again for implantation in mammals [11]. After surgery, the biofuel cell entirely implanted in a freely moving rat delivered $38.7 \mu \mathrm{W}\left(193.5 \mu \mathrm{W} \mathrm{cm}{ }^{-2}\right)$ with an OCV in the range of $0.51-0.66 \mathrm{~V}$. By connecting an external boost converter, the implanted biofuel cell powered a light emitting diode or an electronic thermometer. However, the lifetime of this implanted biofuel cell is, so far, no more than 9 days. Another solution to increase the power of biofuel cells is to integrate biofuel cells with supercapacitors. The groups of Cosnier and Shleev have prototyped hybrid supercapacitors/biofuel cells which use the capacitive properties of carbon nanotubes or polyaniline-modified carbon nanotubes to store high energy densities with charge/discharge cycles [3,35].

It should be noted that the power of biofuel cells is generally related to the amount of enzyme immobilised on the electrode, the electrical wiring with the active site of the enzyme, and an efficient fuel supply within the cell. The typical low concentration of $\mathrm{O}_{2}$ and glucose ( $50 \mu \mathrm{M}$ and $5 \mathrm{mM}$, respectively) in blood also significantly limits biofuel cell performance. Furthermore, these biofuel cells are constituted by, at least, two enzyme systems that must operate at the same $\mathrm{pH}$ (pH 7.4).

Moreover, biofuel cells should be properly sterilised before their introduction into an animal in order to prevent any nosocomial infection which can lead to serious illness. In fact, most of the implanted or partially inserted biofuel cells reported to date were not sterilised, and placed in animals without sterile conditions. There are numerous technical processes to sterilise implants: high pressure steam sterilisation with autoclaves, dry heat (exposure to extreme temperatures higher than $140{ }^{\circ} \mathrm{C}$ ), gas sterilisation with ethylene oxide, cold chemical sterilisation with, for instance, sodium hypochlorite, formaldehyde or ozone, and sterilisation by gamma or X-ray irradiation. Unfortunately, these techniques, which present a more or less penetrating sterilisation effect which depends on the porosity of the biomaterial and packaging material, result in a loss of enzyme activity.

Another parameter that has been largely overlooked regards the biocompatibility of biofuel cells. Implanted biofuel cell devices must first be biocompatible, meaning that they should not cause significant inflammatory reactions or induce toxicity to body tissues. It is therefore necessary to create a barrier or self-contain components of the fuel cell to prevent release of nano-objects and proteins. In previous work, bioelectrodes were wrapped in a dialysis membrane and the biofuel cells subsequently inserted in a biocompatible container such as a dacron ${ }^{\circledR}$ bag $[10,11]$. Unfortunately, the presence of this bag drastically increases the volume of the implant and reduces the diffusion of glucose and oxygen to the biofuel cell electrodes. Another solution would be to cover the bioelectrodes with biocompatible polymers such as collagen, Nafion ${ }^{\circledR}$, polysaccharides (alginate, chitosan), hydrogels based on gelatin, or aliphatic polyesters. However, these additional layers will likely create steric constraints with regard to glucose diffusion and thus reduce the power output of the biofuel cell further. Moreover, the use of biofuel cell devices in blood vessels, which could be mounted on stents, will need hemocompatible devices, which is more constraining than just biocompatibility.

In parallel to the two major roadblocks that affect the power output of biofuel cells: sterilisation and biocompatibility, another major issue with implanted biofuel cells is their long-term operational stability. Although bioelectrodes operate under constant humidity, temperature and $\mathrm{pH}$, enzyme inactivation can occur due to high biocatalytic turnover or inhibition by exogenous or endogenous metabolites present in physiological fluids. For biofuel cell configurations based on mediated electron transfer, with redox mediators present in solution or weakly absorbed on the electrode, leaching of the mediator into the surrounding environment is a concern that leads to reduced operational stability and polluting of the organism. Owing to the difficulty in examining the long-term operational stability of implanted biofuel cells in freely moving or anaesthetised animals, only periodic measurements have been performed and only over a short period of 9-11 days [10,11]. Nevertheless, long term stability of glucose/ $\mathrm{O}_{2}$ biofuel cells has been examined in vitro. For instance, the operational stability of a microneedle biofuel cell was continuously examined in artificial interstitial fluid. This device delivered $75 \%$ of its initial power density after $60 \mathrm{~h}$ of operation [36]. In sweat, a miniature biofuel cell delivered its maximum power continuously for $10 \mathrm{~h}$, with the power output remaining at $65 \%$ of its initial value after this period [37]. Bilewicz and coworkers reported a decay of $20 \%$ of the initial power of $131 \mu \mathrm{W} \mathrm{cm}{ }^{-2}$ after $24 \mathrm{~h}$ of continuous discharge for a biofuel cell based on naphthalene functionalised carbon nanotubes [38]. Di Lorenzo and coworkers reported a flow through miniature biofuel cell based on porous gold, which operated continuously for a period of 30 days and had an operational half-life of approximately 8 days [39]. Biocathodes based on laccase and stored in phosphate buffer are rapidly inhibited at $\mathrm{pH} 7$, but, to prolong lifetimes, can be reactivated at acidic $\mathrm{pH}$ values [40]. The OCV of laccase-based cathodes remains almost constant at around $0.6 \mathrm{~V}$ for one year, highlighting the surprising stability of this enzyme in biofuel cell design.

\section{Recent advances in biocathode configuration}

Most oxygen-reducing biocathodes in enzymatic fuel cell research contain enzymes from the multicopper oxidase (MCO) family. These 
enzymes have a set of four copper centres. A mononuclear copper centre is responsible for the electron transfer between the substrate - or the electrode surface - and a type 2/type 3 trinuclear copper cluster (called TNC) where oxygen is reduced to water (Fig. 2).

The main recent developments in the fabrication of MCO-based bioelectrodes have relied on the controlled orientation of these enzymes on electrodes.

The T1 copper centre of MCOs is responsible for the binding of the phenolic substrate and subsequent electron transfer with the T2/T3 copper centre where oxygen is activated and reduced (Fig. 1) [41,42]. Since this T1 unit is located near the surface of the protein, strategies have been employed to favour the orientation of enzymes and to shorten the distance between the electrode and the T1 centre. Laccases and bilirubin oxidases from specific organisms have been especially chosen for the high redox potential of their T1 copper centre, which is responsible for the low-overpotential oxygen reduction electrocatalysis of only several tens of millivolts at near neutral $\mathrm{pH}$ $[41,42]$. An important work has recently been realised by Armstrong and coworkers on the orientation of laccases from Trametes versicolor on electrodes. It was shown that a set of hydrophobic amino acids, constituting the substrate pocket of the enzyme, could be targeted by hydrophobic groups attached on the surface of the electrode $[43,44]$. Graphite-based electrodes were modified via aryldiazonium electrografting of anthracene or anthraquinone groups. These electrodes have shown superior performances towards the immobilisation and direct electrical wiring of laccases. Several groups have since transferred this strategy to carbon nanotube-based electrodes where diazonium-based chemistry $[38,45]$, electrografting of amines $[46,47]$, and amide coupling [48] chemistries have been employed for controlled attachment of enzymes. We and others have also investigated the non-covalent coupling of hydrophobic groups by modifying pyrene molecules with anthraquinone [49] or anthracene [50] groups. These strategies have led to excellent oxygen reduction electrocataly- sis with maximum catalytic currents of several $\mathrm{mA} \mathrm{cm}^{-2}$ at $\mathrm{pH} 5$. Similar substrate-mimicking strategies have also been employed in cathode design for the orientation of bilirubin oxidases (BOD). In this case, the modification of electrodes with bilirubin or molecules with similar structures led to electron transfer promoting properties towards BO [51-53]. The use of different types of porphyrins, which are biological precursors of bilirubin, has underlined the fact that both structural and electrostatic interactions influence the orientation of the enzyme [54]. Atanassov and coworkers have developed a high performance biocathode based on bilirubin oxidase from Myrothecium verrucaria (Mv) using the covalent linker pyrene-NHS for oriented immobilisation of the enzyme [52]. Other research teams have also demonstrated that the orientation of BOD from $\mathrm{Mv}$ is strongly influenced by negatively-charged groups such as carboxylates on electrode surfaces $[55,56]$. On the contrary, positively-charged groups have a detrimental effect on the wiring of this enzyme by favouring a surface orientation at the opposite side of the T1 centre [55,57]. Lalaoui et al. have recently shown that this behavior cannot be generalised for other BOD enzymes. For instance, BOD from bacillus pumilus exhibits unfavorable orientation on napthoic carboxylate-modified MWCNTs [58]. In a different strategy, laccase mutants from Trametes sp C30 have been specifically modified with a pyrene group, by tagging a lysine residue at the vicinity of the T1 centre. Lalaoui et al. have demonstrated efficient electrocatalytic oxygen reduction by immobilisation of these laccases on MWCNTs and MWCNT/AuNP supramolecular assemblies [59].

Despite these high performances, commonly-used laccases and bilirubin oxidases might have important drawbacks for in vivo applications: low catalytic stability and inhibition by common substances present in physiological fluids such as chloride and urates for laccase and BOD, respectively. Furthermore, laccase shows low activity at neutral $\mathrm{pH}[40]$. Several attempts have been made to replace these enzymes with new mutants, enzymes from other organisms, and with
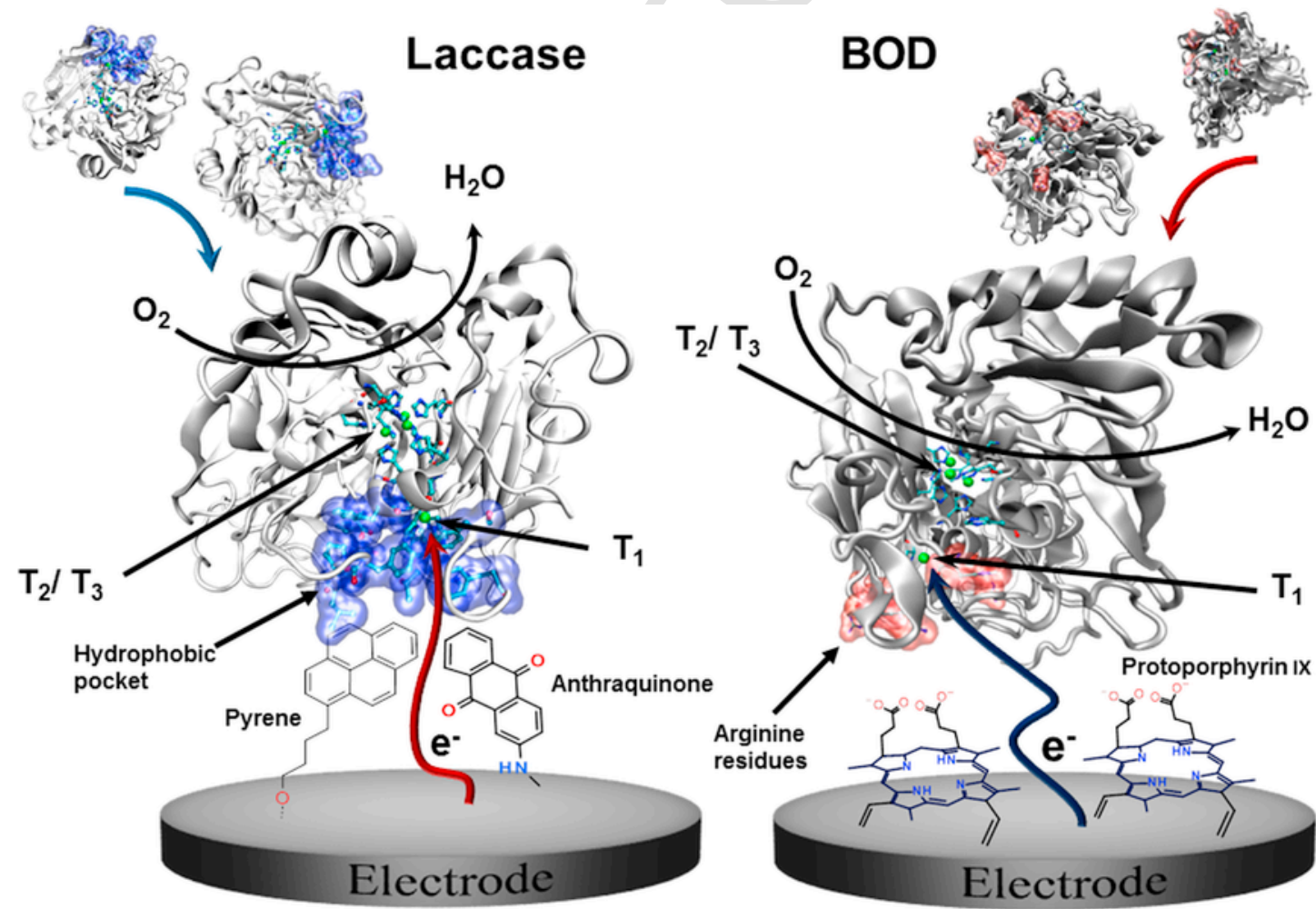

Fig. 2. Schematic presentation of the orientation of BOD and laccase on electrodes for electrocatalytic oxygen reduction. 
novel combinations of enzymes. BOD from Bacillus pumilus, a recently-discovered $\mathrm{MCO}$, has an excellent tolerance of stability towards both urates and chloride as well as other chelators such as EDTA. Direct mutagenesis has improved the resistance of laccases to chlorides and hydroxides [60]. Polyphenol oxidases or tyrosinase, which is composed of a type 3 binuclear copper centre, has recently demonstrated its ability to reduce oxygen by DET at redox potentials of $0.58 \mathrm{~V}$ vs SCE at $\mathrm{pH} 7$ [61]. Even when the redox potential of the enzyme is around two hundred millivolts lower than laccase or BOD, this enzyme is not inhibited by species found in physiological fluids. An original cascade reaction using bioanodes having two enzymes, glucose oxidase (GOx) and horseradish peroxidase (HRP), has also been investigated for the complete reduction of $\mathrm{O}_{2}$ into water [62-64]. GOx oxidises glucose while reducing oxygen to hydrogen peroxide. The produced $\mathrm{H}_{2} \mathrm{O}_{2}$ is then reduced to water by HRP. GOx and HRP were immobilised on CNT-based electrodes and, while GOx generates $\mathrm{H}_{2} \mathrm{O}_{2}$, an efficient DET of HRP could be achieved with a high reduction potential [64]. This enzyme cascade led to the complete reduction of $\mathrm{O}_{2}$ into water by a dual enzymatic/electroenzymatic process at a high potential of $0.84 \mathrm{~V}$ vs NHE. Important developments have also been made on the design of controlled nanostructures for the improvement of enzyme loadings and oxygen mass transport. Different materials with controllable and hierarchical porosity have been especially studied to increase catalyst loading and to enhance oxygen mass transport. In particular, carbon-based materials, such as carbon aerogels [65], carbon cryogels [66], carbon nanofibers [67], carbon microfibers [47], and carbonaceous foams $[68,69]$, have all shown enhanced performances towards the wiring of MCOs and electrocatalytic oxygen reduction.

In order to get closer to the technologically-relevant operation of these enzymes, air-breathing electrodes have been investigated to improve oxygen mass-transport limitations and to circumvent the low solubility of oxygen in water. Laccase or BOD have been integrated in gas-diffusion electrodes (GDE), allowing the biocatalyst to operate at a "three-phasic" interface [70]. These air-breathing biocathodes were finally able to deliver several $\mathrm{mA} \mathrm{cm}{ }^{-2}$ under air without any need for forced oxygen convection using a hydrogen/air enzymatic fuel cell setup [58].

\section{Recent progress on bioanodes based on glucose oxidase (immobilisation and electrical wiring): challenges}

The most commonly used enzyme for glucose oxidising bioanodes is glucose oxidase (GOx) from Aspergillus niger. This biocatalyst provides very high specificity, activity and stability towards $\beta$-D-glucose, present in biological fluids, compared to other glucose oxidising enzymes. Furthermore, the intrinsic co-factor, flavin adenine dinucleotide (FAD), has an advantageous redox potential (around $-0.45 \mathrm{~V}$ vs $\mathrm{Ag} / \mathrm{AgCl}$ ) for use in the design of bioelectrocatalytic bioanodes. Wilson and Turner reviewed the characteristics of GOx and declared it in the early nineties as "an ideal enzyme" for glucose sensor applications [71]. However, for glucose biofuel cells, this enzyme unfortunately poses both advantages and disadvantages. For instance, GOx is a particularly large enzyme with a molecular weight of around $160 \mathrm{kDa}$ and an average diameter of $8 \mathrm{~nm}[71,72]$. The high stability of its catalytic activity is certainly related to its impressive protein shell since the active site and the FAD cofactor are deeply embedded inside the protein matrix. At the same time, the large enzyme size and deeply embedded active site unfortunately make it difficult to achieve electron transfer to the electrode due to long electron tunneling distances and steric constraints, as indicated in Fig. 3. There are still countable examples in the literature where real DET with GOx has been observed. For example, an electrochemical signal due to FAD co-factor residues is discernible using commercial GOx samples. The signal cannot be accounted for by DET if no catalytic current can be measured [2,73-76]. Nanotube based materials seem to be the most appropriate material for optimised electron transfer in biofuel design since the thin and long structure of CNTs facilitates getting close to the redox active site of the enzyme. One strategy to achieve DET with GOx is to use electrodes prepared via compression of CNTs in the presence of enzyme [2]. It is well accepted that only a small quantity of GOx is wired using this approach and that the promising current densities are related to the very high amount of enzyme employed during fabrication. Another strategy to wire GOx is to modify the electrode material with FAD and to use especially produced apo-GOx, where the co-factor has been removed $[77,78]$. The disadvantage here is the lack of availability of apo-GOx. A more reliable strategy to wire GOx is to use advanced redox medi-

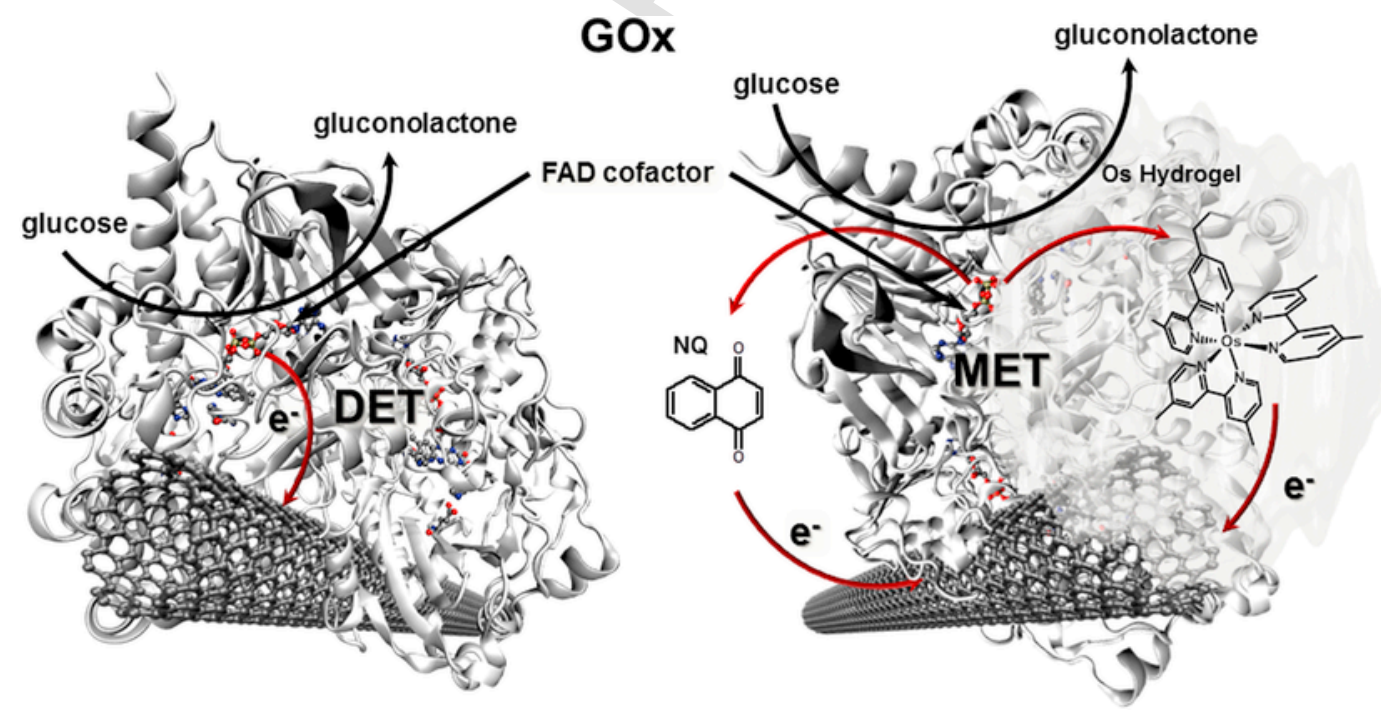

Fig. 3. Sketch of possible electron transfer modes from the active site of GOx to a CNT electrode. Left DET, right MET. 
ators such as osmium based hydrogels and quinones which have emerged as the most promising candidates $[79,80]$.

The advantage of Os based hydrogels is that their redox potential can be modulated and optimised for optimal electron transfer rates by fine tuning of the Os complex structures [81]. Furthermore, the hydrophilic character of the redox hydrogels allows the diffusion of the substrates, for the biocatalysts, and the enzymatically generated products [82]. As a result, these electrodes have proven to be very efficient for construction of glucose oxidase anodes [83]. Leech and coworkers comprehensively studied different Os based hydrogels for a variety of glucose oxidising and oxygen reducing enzymes [84-88]. For example, they investigated enzymatic biofuel cells prepared with [Os(4,4'-dimethoxy-2,2'-bipyridine) 2 (polyvinylimidazole) $\left.{ }_{10} \mathrm{Cl}\right]^{+}$as a mediator for glucose oxidase and [Os(4,4'-dichloro-2,2'-bipyridine $)_{2}$ (polyvinylimidazole $\left.)_{10} \mathrm{Cl}\right]^{+}$as a mediator for different MCOs [84]. The different ligands allowed a satisfying potential window for the optimised glucose biofuel cell and a catalytic current of $43 \mu \mathrm{W} \mathrm{cm}{ }^{-2}$ at $0.25 \mathrm{~V}$ using amine modified graphite electrodes, where the enzymes were crosslinked using poly (ethylene glycol) diglycidyl ether. This configuration also retained $70 \%$ of its initial power output after $24 \mathrm{~h}$. Leech and coworkers also immobilised glucose oxidase via di-epoxide crosslinking within biofilms containing different functionalised osmium complexes on graphite electrodes [85]. The bioelectrodes, prepared with dimethoxy- or dimethylbipyridyl ligands, provided catalytic currents for glucose oxidation of around $30 \mu \mathrm{A} \mathrm{cm}^{-2}$ and $70 \mu \mathrm{A} \mathrm{cm} \mathrm{cm}^{-2}$ at $0.2 \mathrm{~V}$ and $0.35 \mathrm{~V}$ vs $\mathrm{Ag} / \mathrm{AgCl}$, respectively, under pseudo physiological conditions in $5 \mathrm{mmol} \mathrm{L}^{-1}$ glucose solutions. Mano and coworkers have deposited such osmium hydrogels on CNT fibers with great success [89]. A very high performing glucose biofuel cell with a power output of $740 \mu \mathrm{W} \mathrm{cm}{ }^{-2}$ at $0.57 \mathrm{~V}$ could be obtained using the MET setup [90]. The glucose oxidase based bioanode delivered a current density of $10 \mu \mathrm{A} \mathrm{mm}{ }^{-2}$ near $-0.1 \mathrm{~V}$ vs $\mathrm{Ag} / \mathrm{AgCl}$ [91]. However, even though Os based redox polymers efficiently wire glucose oxidase, and lead to clearly enhanced biofuel cell performances, such hydrogels do not yet provide the necessary stability to be competitive with other systems in terms of longterm operation [85].

Bioanode systems have also been investigated based on quinones and, in particular, napthoquinones (NQ), as promising alternatives to mediate electron transfer from glucose oxidase to the electrode. Cosnier and coworkers reported the first wiring of GOx inside CNT disks using NQ and observed a 7 fold increase in catalytic current densities with only a small increase in open circuit potential (OCP) of the bioanode from $-0.45 \mathrm{~V}$ to $-0.2 \mathrm{~V}$ vs SCE [92]. A whole glucose biofuel cell, with laccase as the cathodic biocatalyst, delivered a power output density of $1.54 \mathrm{~mW} \mathrm{~cm}^{-2}, 1.92 \mathrm{~mW} \mathrm{~mL}^{-1}$ and $2.67 \mathrm{~mW} \mathrm{~g}^{-1}$.

The fact that NQ is not immobilised can lead to leakage of this toxic mediator and thus the appropriateness of this approach for implantable glucose biofuel cells must be questioned. Nonetheless, Cosnier and coworkers managed to clearly minimise this negative effect by initially controlling leakage of the mediator. For this approach, an equilibrium was reached via a negatively charged Nafion ${ }^{\circledR}$ based membrane which retained the water soluble naphthohydroquinone, the reduced form of NQ. This stabilised system led to a high performance glucose biofuel cell which retained approximately $20 \%$ of its initial power output after one year with negligible evidence for NQ leakage [40]. A total of $30 \mathrm{mWh}$ of energy was produced, which corresponds to the stored energy in classic $1.5 \mathrm{~V}$ button cell batteries. To date, this represents the world record of produced power for a glucose biofuel cell device.

Since NQ has been shown to lose its wiring capacities when chemically modified and immobilised on electrodes, Minteer and coworkers addressed this problem and tested different setups with
NQ modified hydrogels and NQ modified glucose dehydrogenase (GDH) enzymes. The optimised bioanode of the hydrogel setup yielded a maximum current density of $3.3 \mathrm{~mA} \mathrm{~cm}^{-2}$ at $0 \mathrm{~V}$ vs SCE and an OCP of $-0.25 \mathrm{~V}$ at $\mathrm{pH} 6$ [80]. The same group synthesised a bis naphthoquinonyl-pyrene derivative and functionalised CNTs via $\pi$-stacking interactions. Current densities of $124.5 \pm 0.4 \mu \mathrm{A} \mathrm{cm}{ }^{-2}$ and $166.2 \pm 2.7 \mu \mathrm{A} \mathrm{cm}^{-2}$ at 0 and $0.3 \mathrm{~V}$ vs SCE were recorded using a PQQ dependent GDH with an OCP of $+0.15 \mathrm{~V}$ vs SCE [93]. Unfortunately this naphthoquinone pyrene derivative did not show any activity for MET towards GOx. Despite evidence that immobilised NQ is not appropriate for MET with GOx, this bioanode system may still be regarded as one of the most promising for high performance bioanodes and thus further research is encouraged to overcome these issues.

\section{Advances and limitations of hydrogen/oxygen enzymatic fuel cells}

Another class of intensively studied enzymatic fuel cells is the $\mathrm{H}_{2} / \mathrm{O}_{2}$ biofuel cell. These fuel cells rely on MCOs for the reduction of oxygen at the cathode and hydrogenases for oxidation of $\mathrm{H}_{2}$ at the anode. Hydrogenases are metalloenzymes which catalyse the reversible conversion of $\mathrm{H}_{2}$ into protons. The main families of hydrogenases are $\mathrm{NiFe}$ and $\mathrm{FeFe}$ hydrogenases which have a dinuclear FeFe sulfur cluster or a dinuclear $\mathrm{Ni}-\mathrm{Fe}$ sulfur cluster as their active sites, respectively. A chain of iron-sulfur clusters ensures electron transfer between the surface of the protein and the embedded active site. Several examples have demonstrated that these enzymes can compete with platinum in terms of catalytic efficiency for $\mathrm{H}_{2}$ oxidation [94,95]. However, several important obstacles have to be overcome before these enzymes are realistically operational in hydrogen biofuel cells.

As already discussed, an efficient electron transfer has to be achieved between the enzyme active site and the electrode. METbased electrodes mostly relied on methylviologen (MV)-modified polymers for the entrapment of hydrogenases and for low-potential MET, owing to the excellent match between the redox potential of $\mathrm{MV}^{+} / \mathrm{MV}^{2+}$ and the redox potential of NiFe hydrogenases (Fig. 4, right) $[96,97]$. Owing in particular to progress in surface modification chemistry and nanostructured materials design, several recent achievements have shown highly efficient DET between nanostructured electrodes such as those based on carbon nanotubes with hydrogenases. As for the MCOs, surface modification strategies were developed to favour orientation of the enzyme on electrodes. De Lacey and coworkers have proposed electrochemical aryldiazonium functionalisation of MWCNTs for the grafting of ammonium groups on CNTs [98]. These positively-charged nanostructured electrodes favour the orientation of NiFe from Desulfovibrio gigas, an enzyme which possesses a favourable dipolar moment. Lojou and coworkers showed that surfaces such as gold or CNTs, modified with hydrophilic groups, could favourably interact with the protein residues of NiFe hydrogenases $[58,99]$. Excellent DET properties were achieved with high catalytic current densities for $\mathrm{H}_{2}$ oxidation of several $\mathrm{mA} \mathrm{cm}^{-2}$ (Fig. 4, left).

One major issue when dealing with hydrogenase electrodes for $\mathrm{H}_{2} / \mathrm{O}_{2}$ enzymatic fuel cell applications is their oxygen sensitivity. The mechanism of this sensitivity has been widely investigated and shows that oxygen is inhibiting towards enzyme activity [100]. To circumvent this effect, several strategies have been employed in the design of such enzymatic fuel cells. A simple strategy is to use a separating membrane or low levels of $\mathrm{O}_{2}$ [101]. The most effective strategy to date has been to elaborate and study oxygen-tolerant hydrogenases such as hydrogenase from the hyperthermophilic bacterium Aquifex 


\section{$[\mathrm{NiFe}] \mathrm{H}_{2}$ ase}
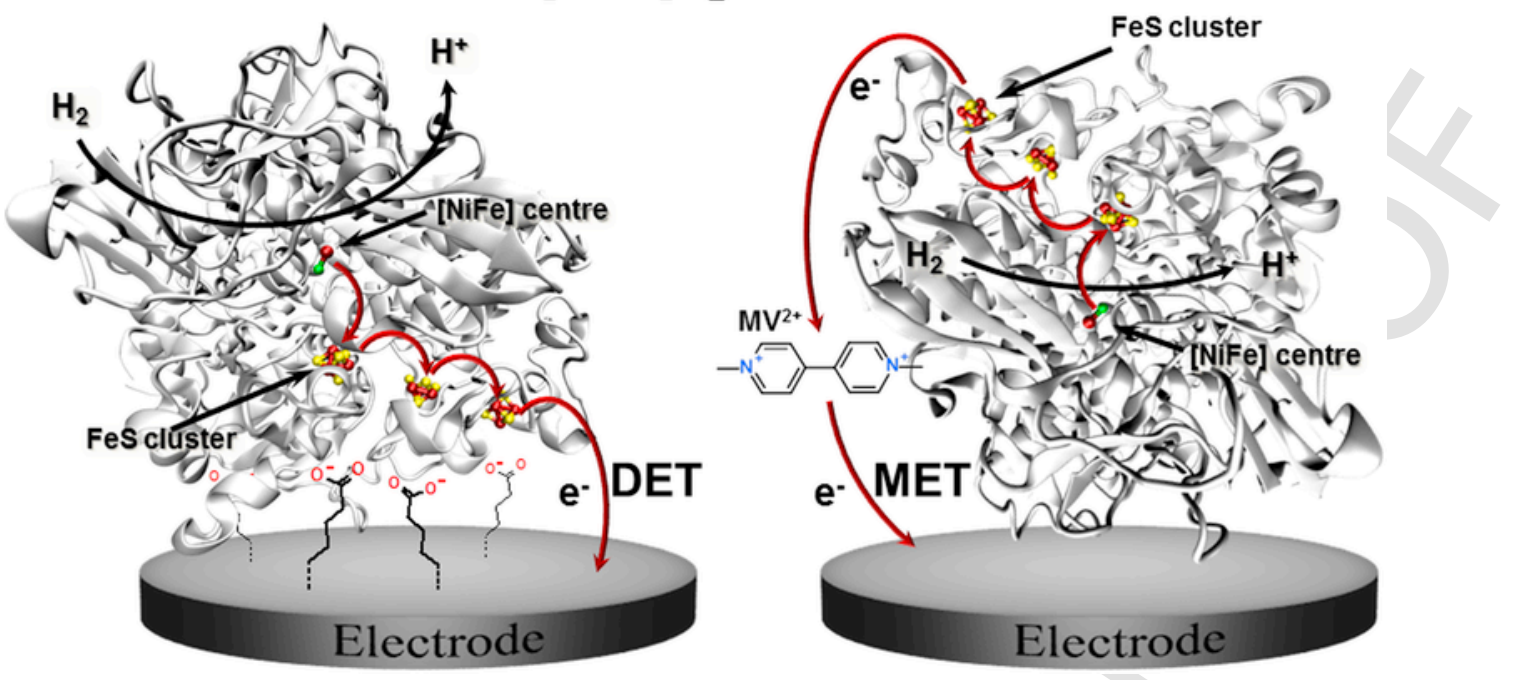

Fig. 4. Sketch of MET (right) and DET (left) modes from the active site of NiFe hydrogenases to an electrode substrate.

aeolicus [102]. The first hydrogen biofuel cells based on oxygen-tolerant $\mathrm{NiFe}$ hydrogenases from $\mathrm{R}$. Eutropha, at the anode, and laccase from Trametes versicolor, at the cathode, were reported by Armstrong and coworkers [103]. The enzymes were adsorbed on graphite electrodes for construction of a fuel cell setup which delivered a maximum power output of $5 \mu \mathrm{W} \mathrm{cm}{ }^{2}$ at $\geq 0.8 \mathrm{~V}$ at $\mathrm{pH} 5$. More recently, through nanostructuration of the electrodes and improvements in controlled enzyme orientation and wiring, clear improvements in power densities have been realised. In particular, the use of carbon nanotubes increased the power density by one order of magnitude to the range of $100-300 \mu \mathrm{W} \mathrm{cm}{ }^{-2}[104,105]$. Subsequently, further improvements in the control of hierarchical porosities of carbon-based electrodes, combined with the use of oxygen-tolerant hydrogenases, have increased power performance. Power densities have been reported up to $0.42 \mathrm{~mW} \mathrm{~cm}^{2}$ at room temperature and $\mathrm{pH} 7$, for mesoporous carbon electrodes [106], and $1.5 \mathrm{~mW} \mathrm{~cm}{ }^{-2}$ at $60^{\circ} \mathrm{C}$ and $\mathrm{pH} 7$, for carbon nanofiber electrodes [67]. Armstrong and $\mathrm{Xu}$ pushed the limits further and assembled several membrane-less hydrogen biofuel cells both in parallel and in series. The best configuration obtained using a series multicell delivered $7.84 \mathrm{~mW}\left(0.149 \mathrm{~mW} \mathrm{~cm}^{-3}\right)$ at $1.22 \mathrm{~V}$ at $20^{\circ} \mathrm{C}$ and $\mathrm{pH} 6$. It should be noted that one individual biofuel cell delivered $600 \mu \mathrm{W}$, which corresponds to a power density of $100 \mu \mathrm{W} \mathrm{cm} \mathrm{cm}^{-2}$ or $500 \mu \mathrm{W} \mathrm{cm}{ }^{-2}$, taking into account effective surface areas of $6 \mathrm{~cm}^{-2}$ and $1.2 \mathrm{~cm}^{-2}$ at the biocathode and bioanode, respectively [15].

A recent study on methylviologen-modified hydrogels using an oxygen sensitive hydrogenase has underlined the advantages brought about by MET. While these types of redox polymers had previously been employed for efficient hydrogenase immobilisation and wiring $[96,97]$, Lubitz, Schuhmann and coworkers showed that methylviologen-based hydrogels could provide several useful functions [107]. On one hand, the MET mode efficiently prevents catalyst deactivation at high potential via the formation of an inhibited form of the NiFe active centre $[107,108]$. On the other hand, these viologens catalyse the reduction of oxygen, thus clearly reducing inhibition of the hydrogenase. Furthermore, these multifunctional redox polymers afford a highly stable immobilisation of hydrogenases via cross-linking, leading overall to a highly-efficient bioanode for electrocatalytic $\mathrm{H}_{2}$ oxidation. This anode was integrated in a biofuel cell using an oversized cathode modified with BOD from Mv. The biofuel cell delivered $0.2 \mathrm{~mW} \mathrm{~cm}^{-2}$ at $40^{\circ} \mathrm{C}$ and $\mathrm{pH} 7$ [107].

\section{New materials}

Nanostructured carbon materials like carbon nanotubes (CNTs) have demonstrated great potential as the conducting substrates in enzymatic bioelectrode design [109]. Most high performance bioelectrodes to date have been fabricated using CNTs due to their high specific surface area and exceptional electronic and mechanical properties which allow enhanced DET and MET [92,110]. Furthermore, CNT materials benefit from being readily modified with organic functional groups, permitting immobilisation, stabilisation and orientation of biocatalysts for enhanced electrical wiring [40,49,54,93].

A wide range of CNT materials has been developed in recent years and consistently demonstrate good performance for electron transfer reactions between the substrate and redox enzymes [111]. High performance CNT bioelectrodes are prepared via drop-casting [62], wetor electro-spinning methods [90,112], direct growth [73], and printing [113] onto a conductive support, by compression into free-standing disks $[2,92]$, or by filtration to give free-standing $[27,63,114]$ or supported CNT films [27,115]. Although efficient electron transfer is readily demonstrated in the laboratory, the adoption of CNTs as a robust, easy-to-process and scalable technology requires additional methodology and rational engineering. Ideally a CNT bioelectrode would be fabricated without the use of additives such as surfactants, binders and fillers, which can reduce conductivity and may lead to additional fouling in solution. In this respect, tremendous advances have been made towards implantable enzymatic fuel cell devices using CNT disk and buckypaper electrodes. These CNT electrodes are generally obtained by straightforward, low-cost compression and filtration methods, respectively.

The CNT disk bioelectrodes are obtained by compression of an aqueous slurry of CNTs that often contains an enzyme and other components such as catalase and electron mediators $[2,11,40]$. The compression of CNTs with enzyme enables intimate contact between the surface of CNTs and the enzyme in a large surface area 3D-structured matrix. These electrodes were exploited for production of the pioneering biofuel cells implanted in rats and shown to be stable for 9 days [11]. Incorporation of an electron transfer mediator such as NQ 
in the CNT slurry before compression improves catalytic performance for glucose oxidase, and led to a biofuel cell power density of $1.5 \mathrm{mWcm}^{-2}$ [92]. Such compressed CNT/enzyme electrodes benefit from good and stable power output, although the very high loadings of enzyme used during compression is a major limiting factor. Furthermore, CNT disk electrodes tend to be brittle and difficult to manipulate, leading to potential CNT nanotube release into the local environment. The disks also have diffusional transport and electron transfer limitations due to the large electrode thickness $(1 \mathrm{~mm})$ and porous nanotube structure with limited nanotube interconnections.

Compressed CNT/enzyme bioelectrodes have also been used ex vivo for the development of a novel biobattery system for energy storage and conversion, with a view to overcoming the power limitations of classic glucose $/ \mathrm{O}_{2}$ biofuel cells for implantable devices. Cosnier and coworkers and others, have reported an exciting advance in prototyping whereby the CNT matrix was exploited as both a supercapacitor and an electrode material for construction of a hybrid biofuel cell/supercapacitor $[3,35]$. CNT materials are among the best type of supercapacitors available and hence are ideal for such applications $[116,117]$. The prototype devices enable short, high power discharge cycles via redox enzymes whilst being continuously recharged via biocatalytic energy conversion. The best performing device to date exhibited operational stability for at least 40,000 pulses of $2 \mathrm{~mW}$ for 5 days and had one of the highest power outputs for a hybrid biofuel cell device achieved to date of $16 \mathrm{~mW}$ at $0.5 \mathrm{~V}$ [35]. Further gains in power output should be possible by construction of a cell with shorter distances between the electrodes, for example, as reported by Bilewicz and coworkers. A decrease in inter-electrode distance from $2 \mathrm{~cm}$ to $0.1 \mathrm{~cm}$ reduced the potential drop between the electrodes and resulted in a power increase by a factor of two to $2.2 \pm 0.3 \mathrm{~mW}$ [118].

An attractive alternative to CNT disk bioelectrodes with excellent properties for implantable electrodes are CNT buckypaper electrodes $[115,119,120]$. These electrodes have only started to emerge over the last 5 years since the early reports from Hussein and coworkers [121]. Buckypaper is typically obtained by vacuum filtration of a dispersion of CNTs to obtain a thin film with a typical thickness in the range of $20-300 \mu \mathrm{m}$. The film is held together by van der Waals attractions and CNT interlocking. Its properties as an electrode substrate are largely influenced by the purity and density of the CNTs used and the homogeneity of the suspension. Buckypaper electrodes can be obtained via a commercial source or via reported methods $[121,122]$. Like CNT disks, buckypapers tend to be brittle; however, they are typically denser than CNT disks and less prone to degradation in solution. Compared to CNT disks, free-standing BP electrodes require considerably smaller amounts of enzyme to obtain competitive current densities. Furthermore, BP electrodes benefit from being lighter, more compact and more easily processed into different shapes and sizes.

Buckypaper modified by pyrene derivatives via pi-stacking with the surface of CNTs has proven to be a very successful electrode system for in vivo biofuels, as previously mentioned, in snails, clams and lobsters $[23,27,28]$. For implantable devices, Katz and coworkers used buckypaper electrodes for DET via a bifunctional pyrene-activated ester cross-linker with a pyrroloquinoline quinone dependent glucose dehydrogenase (anode) and laccase (cathode) (Fig. 5). The implanted biofuel cells were operated, impressively, for more than two weeks in a moving organism [23].

Using the same type of electrode, the first sustainable operation of a pacemaker was demonstrated in a system mimicking human physiological conditions, highlighting the promise of these electrode materials [33]. Towards the goal of remote autonomous operation, recent research from Katz and coworkers demonstrated the first in vivo biofuel cells equipped with microelectronics for wireless transmission $[123,124]$. However, improvements in power output are still required to ensure self-activation and meaningful information transmission.

The biofuel cell embedded in a contact lens, developed by Minteer and coworkers, exploited in particular the mechanical flexibility of buckypaper electrodes. This biofuel cell delivered a power density of $8 \mu \mathrm{W} \mathrm{cm}{ }^{-2}$ at an OCP of $0.4 \mathrm{~V}$ from human tears [20]. Commonly used electrode substrates such as Toray paper lacked sufficient flexibility for this application. The amount of power demonstrated using the fully integrated device was sufficient to power actual ocular devices for $12-16 \mathrm{~h}$, although the majority of power was consumed within the first $4 \mathrm{~h}$. The loss of power over time was attributed to leaching of the physisorbed, electropolymerised methylene green mediator over time. Leaching of organic material is a significant toxicity issue and as such significant improvements in surface engineering are required.

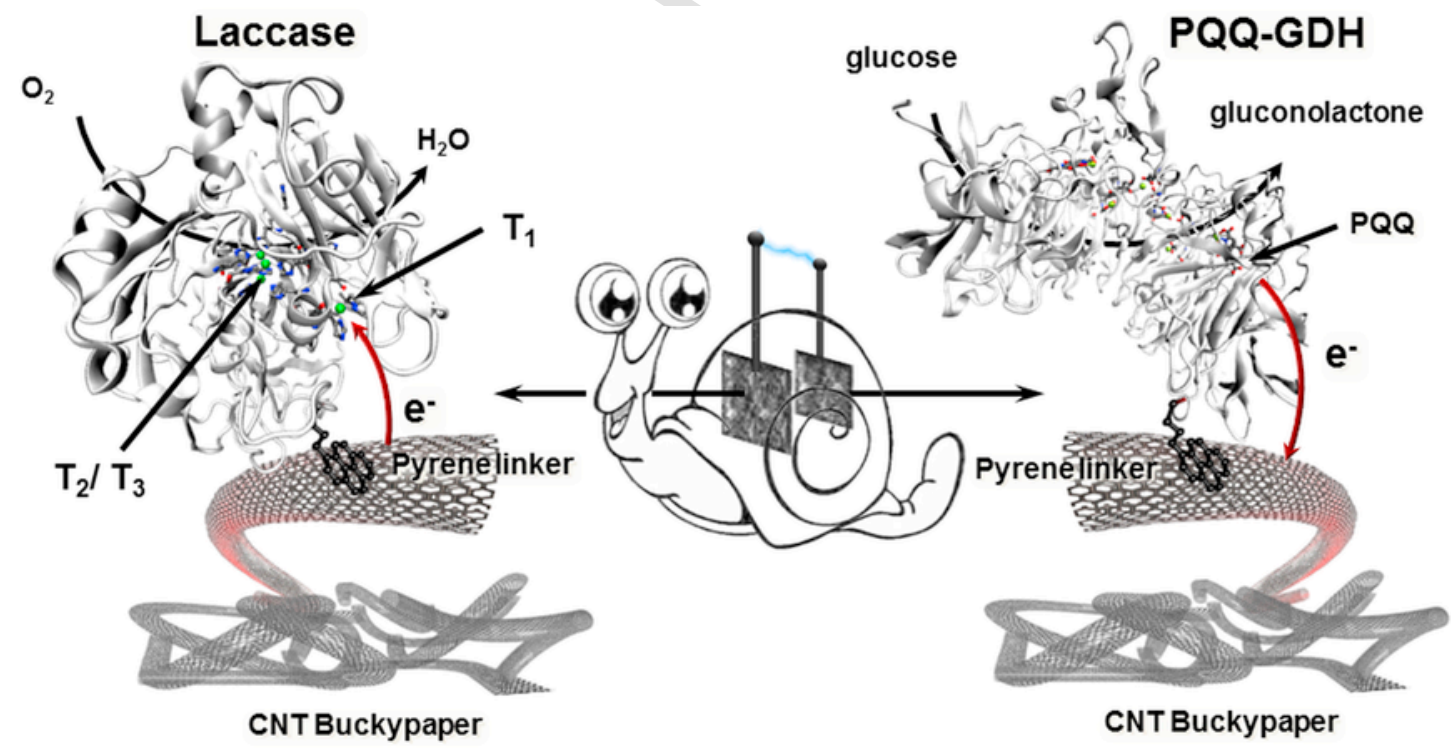

Fig. 5. Cartoon of the buckypaper based bioelectrodes pierced into the body of a snail. 
The use of advanced buckypaper materials to construct and improve gas-diffusional air breathing (GDAB) electrodes has also been demonstrated $[70,125,126]$. Such electrodes operate by increasing the amount of accessible $\mathrm{O}_{2}$ in a fuel cell and are attractive to overcome problems with low levels of solution $\mathrm{O}_{2}$ in living systems. Atanassov and coworkers developed the first paper-based air-breathing electrode using teflonised carbon black, for the gas diffusion layer, and commercially-available buckypaper as the electrode substrate for enzyme wiring [126]. Incorporation of buckypaper with the carbon black layer, with bilirubin oxidase as the catalyst, improved performance significantly from $200 \pm 30 \mu \mathrm{A} \mathrm{cm}^{-2}$ to $475 \pm 90 \mu \mathrm{A} \mathrm{cm}^{-2}$ at $0 \mathrm{~V}\left(\sim 250 \mu \mathrm{A} \mathrm{cm}^{-2}\right.$ at $\left.0.3 \mathrm{~V}\right) \mathrm{vs} \mathrm{Ag} / \mathrm{AgCl}$. After further optimisation, the electrodes were able to output currents up to $755 \pm 39 \mu \mathrm{A} \mathrm{cm}^{-2}$ at $0.3 \mathrm{~V}$ vs $\mathrm{Ag} / \mathrm{AgCl}[125]$. The higher cathodic performance with the incorporation of buckypaper is attributed to the higher enzyme loadings, lower hydrophobicity and improved electrochemical properties compared to teflonised carbon black.

An effective approach to improve CNT material stability is to use bifunctional crosslinking molecules capable of bonding of CNTs [63]. Recent work by Bourourou et al. demonstrated the formation of a robust free-standing BP via pyrene-ABTS (bis-pyrene-2,2'-azinobis(3-ethylbenzothiazoline-6-sulfonic acid)) as a simple platform for electrical wiring with enzyme adsorbed on the surface or present in solution [114]. However, the close proximity of the two pyrene groups in this molecule limits the amount of structural reinforcement due to a low probability of connecting two CNTs. A more effective approach is to incorporate a long linear polymer chain bearing several cross-linking groups, as reported recently [122]. In this work, a polynorbornene monomer with pyrene groups was introduced into the CNT dispersion during fabrication, giving improved physical stability and flexibility, and good performance for a laccase-modified electrode (Fig. 6). Use of such polymers for advancing CNT bioelectrodes requires careful attention to avoid poorly conducting materials that provide inefficient electron transfer and diffusional barriers. Nevertheless, use of small amounts of polymer of around $20 \mathrm{wt} \%$ should maintain good conductivity whilst maximising chemical functionality and mechanical stability.

Further improvements in CNT material stability can be afforded by improving the alignment and packing density of the matrix [127], or by integration of resins and carbon fibers [128].

CNT fibers have become prominent candidates in biofuel design due to the possibility to form miniaturised electrocatalytic bioelectrodes with porous high surface area architectures. CNT fibers can be produced by electrospinning [129], or by wet spinning methods $[89,130]$, where the diameter of these fibers range from several tenths of micrometers down to a few hundreds of nanometers. A convenient technique to produce fibers at the submicron scale is electrospinning. However, since this technique is based on strong polarisation at high voltages, conductive additives can provoke short circuits, thus preventing the formation of fibers. In order to produce fiber electrodes, the required conductivity properties of the electrospun material are obtained by metallic coating [131], annealing [132-134], or by carefully employing conductive fillers at low concentrations [135]. Zheng and coworkers reported electrospun collagen-CNTs nanofibers for preparation of both the anode and cathode in a glucose $/ \mathrm{O}_{2}$ biofuel cell setup [136]. A power density of $14 \mu \mathrm{W} \mathrm{cm}{ }^{-2}$ could be obtained with this electrospun-nanofiber-based glucose biofuel cell. An original strategy developed by Cosnier and coworkers for laccase wiring is based on the use of electrospun polyacrylonitrile (PAN)CNT fiber modified electrodes after annealing [112]. After a standard immobilisation technique, leading to randomly oriented laccases on these fibers, about one third of the enzymes provided DET for $\mathrm{O}_{2}$ reduction. The current density was doubled by using a molecular plug based on the previously mentioned bis-pyrene-ABTS, leading to a maximum current density of $100 \mu \mathrm{A} \mathrm{cm}^{-2}$. Conductive CNT fibers with high tensile strength, produced by wet-spinning and subsequent annealing [89], were coated with enzyme containing osmium hydrogels [90]. The Os mediators increased very efficiently the electron transfer yield and were exploited in a miniaturised glucose biofuel cell setup, consisting of two micro bioelectrodes. Using this approach, an excellent power density of $740 \mu \mathrm{W} \mathrm{cm} \mathrm{cm}^{-2}$ at $0.57 \mathrm{~V}$ at $\mathrm{pH}$

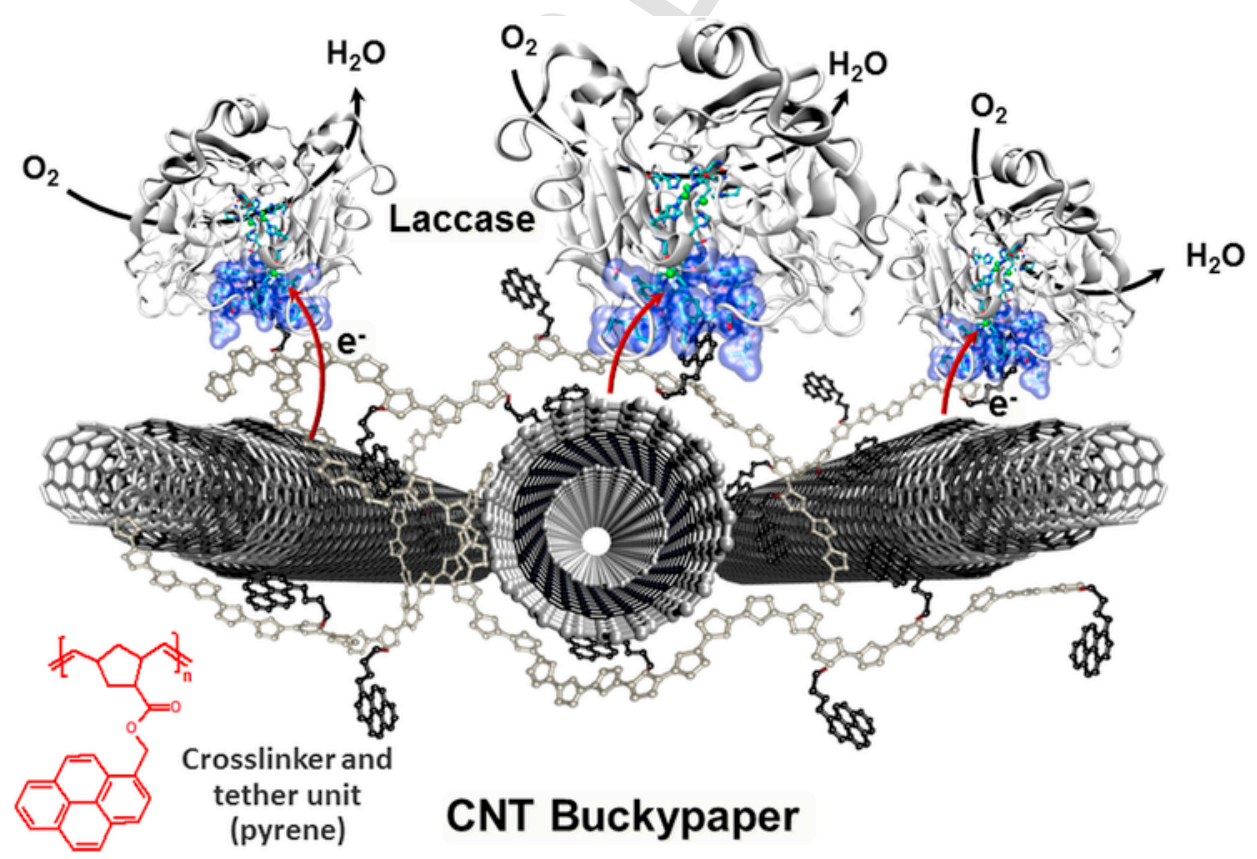

Fig. 6. Sketch of a MWCNT buckypaper formed and stabilised with a functional polymer. 
7.2 was observed. Another innovative approach to wire enzymes to CNT fibers for biofuel cell applications was reported by Baughman and coworkers [5]. To introduce mediator and enzyme to these fibers, the authors used a twisting based yarn spinning process [137]. This methodology permits the formation of extremely well defined 3D carbon nanostructures. The final glucose biofuel cell provided an OCV of $0.70 \mathrm{~V}$ and gave a maximum power density of $2.18 \mathrm{~mW} \mathrm{~cm}^{-2}$. Furthermore, the obtained bioelectrode yarns are sufficiently robust that they can be woven into textiles with a sewing machine, opening up the exciting possibility of automated fabrication of wearable bioelectrodes.

\section{Conclusions}

The possibility of generating power using biological catalysts has now greatly surpassed the proof of concept stage and represents an attractive complementary alternative to other power systems which convert mechanical, thermal, or photovoltaic energy into electricity. Besides the attraction of biofuel cells as portable power sources for miniaturised electronics such as mobile phones, the possibility to selfpower implanted medical devices using the body is particularly exciting. It is greatly accepted that future implantable devices will help to save lives, improve health and prevent diseases. However, there are still many challenging obstacles to overcome before implanted biofuel devices can get close to becoming a commercial reality. Future implanted biofuel cells will undoubtedly exploit glucose and will need to permanently output the required power on the order of many months, ideally years, to become competitive with currently used batteries. Future work is required to ensure both short and long term implants are safe, stable and reliable to prevent issues including foreign body rejection, infection and inflammation.

To overcome critical issues concerning solution $\mathrm{pH}$ and the fragility of enzymes, it may be necessary to use genetically modified enzymes to confer a greater degree of resistance. Another likely solution lies in the development of strategies to periodically renew the enzyme itself, a concept initially described by Kerzenmacher and coworkers [138]. A promising strategy might thus involve non-immobilised enzymes confined in hollow electrodes with a membrane to supply fresh enzyme by perfusion. Another alternative strategy to increase the power and operational lifetime of biofuels would be to employ purely abiotic catalysts $[124,139]$ or only one enzymatic anode together with a non-enzymatic cathode. The development of such hybrid biofuel cells, for example, utilising metal nanoparticles as the catalyst at the cathode, may circumvent complications including inhibition encountered by enzymatic biocathodes under physiological conditions.

Enzymatic biofuel cell technology might therefore be considered as a fundamental research field for a long time until, after further technological breakthroughs, devices become commercially viable. The great potential of biofuel cell devices to be implanted in a wide range of future portable and implanted devices will nevertheless continue to attract tremendous interest in these exciting and potentially revolutionary technologies.

\section{Acknowledgements}

The present work was partially supported by the Labex ARCANE (ANR-11-LABX-0003-01) and from the ANR Investissements d'avenir - Nanobiotechnologies 10-IANN-0-02.

\section{References}

[1] T. Nöll, G. Nöll, Chem. Soc. Rev. 40 (2011) 3564-3576.
[2] A. Zebda, C. Gondran, A. Le Goff, M. Holzinger, P. Cinquin, S. Cosnier, Nat. Commun. 2 (2011) 370

[3] D. Pankratov, P. Falkman, Z. Blum, S. Shleev, Energy Environ. Sci. 7 (2014) 989-993.

[4] T. Miyake, S. Yoshino, T. Yamada, K. Hata, M. Nishizawa, J. Am. Chem. Soc. 133 (2011) 5129-5134.

[5] C.H. Kwon, S.-H. Lee, Y.-B. Choi, J.A. Lee, S.H. Kim, H.-H. Kim, G.M. Spinks, G.G. Wallace, M.D. Lima, M.E. Kozlov, R.H. Baughman, S.J. Kim, Nat. Commun. 5 (2014) 3928.

[6] Z. Zhu, T. Kin Tam, F. Sun, C. You, Y.H. Percival Zhang, Nat. Commun. 5 (2014).

[7] S. Cosnier, A. Le Goff, M. Holzinger, Electrochem. Commun. 38 (2014) 19-23.

[8] G. Slaughter, T. Kulkarni, J. Biochip Tissue Chip 5 (2015) 111

[9] M. Rasmussen, S. Abdellaoui, S.D. Minteer, Biosens. Bioelectron. 76 (2016) 91-102.

[10] P. Cinquin, C. Gondran, F. Giroud, S. Mazabrard, A. Pellissier, F. Boucher, J.-P. Alcaraz, K. Gorgy, F. Lenouvel, S. Mathé, P. Porcu, S. Cosnier, e10476, PLoS One 5 (2010).

[11] A. Zebda, S. Cosnier, J.-P. Alcaraz, M. Holzinger, A. Le Goff, C. Gondran, F. Boucher, F. Giroud, K. Gorgy, H. Lamraoui, P. Cinquin, Sci. Rep. 3 (2013) 1516 .

[12] P. Chenevier, L. Mugherli, S. Darbe, L. Darchy, S. DiManno, P.D. Tran, F. Valentino, M. Iannello, A. Volbeda, C. Cavazza, V. Artero, Comptes Rendus Chim. 16 (2013) 491-505.

[13] E. Lojou, Electrochim. Acta 56 (2011) 10385-10397.

[14] A. de Poulpiquet, D. Ranava, K. Monsalve, M.-T. Giudici-Orticoni, E. Lojou, ChemElectroChem 1 (2014) 1724-1750.

[15] L. Xu, F.A. Armstrong, RSC Adv. 5 (2015) 3649-3656.

[16] B.A. Amar, B.A. Kouki, H. Cao, Sensors 15 (2015).

[17] A.J. Bandodkar, J. Wang, Electroanalysis (2016) http://dx.doi.org/10.1002/ elan.201600019 (in press).

[18] W. Jia, G. Valdés-Ramírez, A.J. Bandodkar, J.R. Windmiller, J. Wang, Angew. Chem. Int. Ed. 52 (2013) 7233-7236.

[19] D. Pankratov, E. González-Arribas, Z. Blum, S. Shleev, Electroanalysis (2016) http://dx.doi.org/10.1002/elan.201501116 (in press).

[20] R.C. Reid, S.D. Minteer, B.K. Gale, Biosens. Bioelectron. 68 (2015) $142-148$.

[21] S. Cosnier, J.J. Fombon, P. Labbé, D. Limosin, Sensors Actuators B Chem. 59 (1999) 134-139.

[22] S. Cosnier, C. Innocent, L. Allien, S. Poitry, M. Tsacopoulos, Anal. Chem. 69 (1997) 968-971.

[23] L. Halámková, J. Halámek, V. Bocharova, A. Szczupak, L. Alfonta, E. Katz, J. Am. Chem. Soc. 134 (2012) 5040-5043.

[24] M. Rasmussen, R.E. Ritzmann, I. Lee, A.J. Pollack, D. Scherson, J. Am Chem. Soc. 134 (2012) 1458-1460.

[25] K. Shoji, Y. Akiyama, M. Suzuki, T. Hoshino, N. Nakamura, H. Ohno, K. Morishima, Biomed. Microdevices 14 (2012) 1063-1068.

[26] K. Shoji, Y. Akiyama, M. Suzuki, N. Nakamura, H. Ohno, K. Morishima, Biosens. Bioelectron. 78 (2016) 390-395.

[27] A. Szczupak, J. Halámek, L. Halámková, V. Bocharova, L. Alfonta, E. Katz, Energy Environ. Sci. 5 (2012) 8891-8895.

[28] K. MacVittie, J. Halamek, L. Halamkova, M. Southcott, W.D. Jemison, R. Lobel, E. Katz, Energy Environ. Sci. 6 (2013) 81-86.

[29] F.C.P.F. Sales, R.M. Iost, M.V.A. Martins, M.C. Almeida, F.N. Crespilho, Lab a Chip 13 (2013) 468-474.

[30] J.A. Castorena-Gonzalez, C. Foote, K. MacVittie, J. Halámek, L. Halámková, L.A. Martinez-Lemus, E. Katz, Electroanalysis 25 (2013) 1579-1584.

[31] H. Cheng, P. Yu, X. Lu, Y. Lin, T. Ohsaka, L. Mao, Analyst 138 (2013) 179-185.

[32] T. Miyake, K. Haneda, N. Nagai, Y. Yatagawa, H. Onami, S. Yoshino, T. Abe, M. Nishizawa, Energy Environ. Sci. 4 (2011) 5008-5012.

[33] M. Southcott, K. MacVittie, J. Halamek, L. Halamkova, W.D. Jemison, R. Lobel, E. Katz, Phys. Chem. Chem. Phys. 15 (2013) 6278-6283.

[34] S. Cosnier, M. Holzinger, A.L. Goff, A. Zebda, In: Université Joseph Fourier, 2010CNRS

[35] C. Agnès, M. Holzinger, A. Le Goff, B. Reuillard, K. Elouarzaki, S. Tingry, S. Cosnier, Energy Environ. Sci. 7 (2014) 1884-1888.

[36] G. Valdés-Ramírez, Y.-C. Li, J. Kim, W. Jia, A.J. Bandodkar, R. Nuñez-Flores, P.R. Miller, S.-Y. Wu, R. Narayan, J.R. Windmiller, R. Polsky, J. Wang, Electrochem. Commun. 47 (2014) 58-62.

[37] M. Falk, D. Pankratov, L. Lindh, T. Arnebrant, S. Shleev, Fuel Cells 14 (2014) 1050-1056.

[38] M. Karaśkiewicz, E. Nazaruk, K. Żelechowska, J.F. Biernat, J. Rogalski, R. Bilewicz, Electrochem. Commun. 20 (2012) 124-127.

[39] H. du Toit, M. Di Lorenzo, Biosens. Bioelectron. 69 (2015) 199-205.

[40] B. Reuillard, C. Abreu, N. Lalaoui, A. Le Goff, M. Holzinger, O. Ondel, F. Buret, S. Cosnier, Bioelectrochemistry 106 (2015) 73-76.

[41] N. Mano, L. Edembe, Biosens. Bioelectron. 50 (2013) 478-485. 
[42] A. Le Goff, M. Holzinger, S. Cosnier, Cell. Mol. Life Sci. 72 (2015) 941-952.

[43] C.F. Blanford, C.E. Foster, R.S. Heath, F.A. Armstrong, Faraday Discuss. 140 (2009) 319-335.

[44] C.F. Blanford, R.S. Heath, F.A. Armstrong, Chem. Commun. 0 (2007) 1710-1712.

[45] E. Nazaruk, K. Sadowska, J. Biernat, J. Rogalski, G. Ginalska, R. Bilewicz, Anal. Bioanal. Chem. 398 (2010) 1651-1660.

[46] M. Sosna, J.-M. Chretien, J.D. Kilburn, P.N. Bartlett, Phys. Chem. Chem. Phys. 12 (2010) 10018-10026.

[47] M. Sosna, L. Stoica, E. Wright, J.D. Kilburn, W. Schuhmann, P.N. Bartlett, Phys. Chem. Chem. Phys. 14 (2012) 11882-11885

[48] M.T. Meredith, M. Minson, D. Hickey, K. Artyushkova, D.T. Glatzhofer, S.D. Minteer, ACS Catal. 1 (2011) 1683-1690.

[49] M. Bourourou, K. Elouarzaki, N. Lalaoui, C. Agnès, A. Le Goff, M. Holzinger, A. Maaref, S. Cosnier, Chemistry 19 (2013) 9371-9375.

[50] F. Giroud, S.D. Minteer, Electrochem. Commun. 34 (2013) 157-160.

[51] J.A. Cracknell, T.P. McNamara, E.D. Lowe, C.F. Blanford, Dalton Trans. 40 (2011) 6668-6675.

[52] R.J. Lopez, S. Babanova, Y. Ulyanova, S. Singhal, P. Atanassov, ChemElectroChem 1 (2014) 241-248.

[53] K. So, S. Kawai, Y. Hamano, Y. Kitazumi, O. Shirai, M. Hibi, J. Ogawa, K Kano, Phys. Chem. Chem. Phys. 16 (2014) 4823-4829.

[54] N. Lalaoui, A. Le Goff, M. Holzinger, S. Cosnier, Chem. - A Eur. J. 21 (2015) 16868-16873.

[55] M. Tominaga, M. Ohtani, I. Taniguchi, Phys. Chem. Chem. Phys. 10 (2008) 6928-6934.

[56] L. dos Santos, V. Climent, C.F. Blanford, F.A. Armstrong, Phys. Chem. Chem. Phys. 12 (2010) 13962-13974.

[57] K. Murata, K. Kajiya, N. Nakamura, H. Ohno, Energy Environ. Sci. 2 (2009) 1280-1285.

[58] N. Lalaoui, A. de Poulpiquet, R. Haddad, A. Le Goff, M. Holzinger, S. Gounel, M. Mermoux, P. Infossi, N. Mano, E. Lojou, S. Cosnier, Chem. Commun. 51 (2015) 7447-7450.

[59] N. Lalaoui, P. Rousselot-Pailley, V. Robert, Y. Mekmouche, R. Villalonga, M. Holzinger, S. Cosnier, T. Tron, A. Le Goff, ACS Catal. 6 (2016) 1894-1900.

[60] Diana M. Mate, D. Gonzalez-Perez, M. Falk, R. Kittl, M. Pita, Antonio L. De Lacey, R. Ludwig, S. Shleev, M. Alcalde, Chem. Biol. 20 (2013) 223-231.

[61] B. Reuillard, A. Le Goff, C. Agnès, A. Zebda, M. Holzinger, S. Cosnier, Electrochem. Comm. 20 (2012) 19-22.

[62] C. Agnès, B. Reuillard, A. Le Goff, M. Holzinger, S. Cosnier, Electrochem. Commun. 34 (2013) 105-108.

[63] K. Elouarzaki, M. Bourourou, M. Holzinger, A. Le Goff, R. Marks, S. Cosnier, Energy Environ. Sci. 8 (2015) 2069-2074

[64] B. Reuillard, A. Le Goff, M. Holzinger, S. Cosnier, J. Mater. Chem. B 2 (2014) 2228-2232.

[65] S. Tsujimura, Y. Kamitaka, K. Kano, Fuel Cells 7 (2007) 463-469.

[66] S. Tsujimura, E. Suraniti, F. Durand, N. Mano, Electrochim. Acta 117 (2014) 263-267.

[67] A. de Poulpiquet, A. Ciaccafava, R. Gadiou, S. Gounel, M.T. Giudici-Orticoni, N. Mano, E. Lojou, Electrochem. Commun. 42 (2014) 72-74.

[68] V. Flexer, N. Brun, M. Destribats, R. Backov, N. Mano, Phys. Chem. Chem. Phys. 15 (2013) 6437-6445.

[69] V. Flexer, N. Brun, O. Courjean, R. Backov, N. Mano, Energy Environ. Sci. 4 (2011) 2097-2106.

[70] C. Lau, E.R. Adkins, R.P. Ramasamy, H.R. Luckarift, G.R. Johnson, P. Atanassov, Adv. Energy Mater. 2 (2012) 162-168.

[71] R. Wilson, A.P.F. Turner, Biosens. Bioelectron. 7 (1992) 165-185.

[72] S.B. Bankar, M.V. Bule, R.S. Singhal, L. Ananthanarayan, Biotechnol. Adv. 27 (2009) 489-501.

[73] D. Ivnitski, B. Branch, P. Atanassov, C. Apblett, Electrochem. Comm. 8 (2006) 1204-1210.

[74] J. Liu, A. Chou, W. Rahmat, M.N. Paddon-Row, J.J. Gooding, Electroanalysis 17 (2005) 38-46.

[75] K. Min, J.H. Ryu, Y.J. Yoo, Biotechnol. Bioprocess Eng. 15 (2010) 371-375.

[76] Z. Wang, S. Liu, P. Wu, C. Cai, Anal. Chem. 81 (2009) 1638-1645.

[77] Y. Xiao, F. Patolsky, E. Katz, J.F. Hainfeld, I. Willner, Science 299 (2003) 1877-1881.

[78] F. Patolsky, Y. Weizmann, I. Willner, Angew. Chem. Int. Ed. 43 (2004) 2113-2117.

[79] R. Kumar, D. Leech, J. Electrochem. Soc. 161 (2014) H3005-H3010.

[80] R.D. Milton, D.P. Hickey, S. Abdellaoui, K. Lim, F. Wu, B. Tan, S.D. Minteer, Chem. Sci. 6 (2015) 4867-4875.

[81] R.J. Forster, D.A. Walsh, N. Mano, F. Mao, A. Heller, Langmuir 20 (2003) $862-868$.

[82] A. Heller, J. Phys. Chem. 96 (1992) 3579-3587.

[83] T.J. Ohara, R. Rajagopalan, A. Heller, Anal. Chem. 65 (1993) 3512-3517.
[84] S. Rengaraj, P. Kavanagh, D. Leech, Biosens. Bioelectron. 30 (2011) 294-299.

[85] P.Ó. Conghaile, S. Kamireddy, D. MacAodha, P. Kavanagh, D. Leech, Anal. Bioanal. Chem. 405 (2013) 3807-3812.

[86] F. Barrière, Y. Ferry, D. Rochefort, D. Leech, Electrochem. Commun. 6 (2004) 237-241.

[87] M.N. Zafar, F. Tasca, S. Boland, M. Kujawa, I. Patel, C.K. Peterbauer, D. Leech, L. Gorton, Bioelectrochemistry 80 (2010) 38-42.

[88] F. Barrière, P. Kavanagh, D. Leech, Electrochim. Acta. 51 (2006) 5187-5192.

[89] B. Vigolo, A. Penicaud, C. Coulon, C. Sauder, R. Pailler, C. Journet, P. Bernier, P. Poulin, Sci. Wash. D.C. 290 (2000) 1331-1334.

[90] F. Gao, L. Viry, M. Maugey, P. Poulin, N. Mano, Nat. Commun. 1 (2010) 2.

[91] N. Mano, F. Mao, A. Heller, J. Am. Chem. Soc. 124 (2002) 12962-12963.

[92] B. Reuillard, A. Le Goff, C. Agnès, M. Holzinger, A. Zebda, C. Gondran, K Elouarzaki, S. Cosnier, Phys. Chem. Chem. Phys. 15 (2013) 4892-4896.

[93] F. Giroud, R.D. Milton, B.-X. Tan, S.D. Minteer, ACS Catal. 5 (2015) $1240-1244$

[94] A.K. Jones, E. Sillery, S.P.J. Albracht, F.A. Armstrong, Chem. Commun. (2002) 866-867.

[95] T. Matsumoto, S. Eguchi, H. Nakai, T. Hibino, K.-S. Yoon, S. Ogo, Angew. Chem. Int. Ed. 53 (2014) 8895-8898.

[96] A.A. Karyakin, S.V. Morozov, O.G. Voronin, N.A. Zorin, E.E. Karyakina, V.N. Fateyev, S. Cosnier, Angew. Chem. Int. Ed. 46 (2007) 7244-7246.

[97] J. Baur, A. Le Goff, S. Dementin, M. Holzinger, M. Rousset, S. Cosnier, Int J. Hydrogen Energy 36 (2011) 12096-12101.

[98] M.A. Alonso-Lomillo, O. Ruediger, A. Maroto-Valiente, M. Velez, I. Rodriguez-Ramos, F.J. Munoz, V.M. Fernandez, A.L. De Lacey, Nano Lett. 7 (2007) 1603-1608.

[99] A. Ciaccafava, P. Infossi, M. Ilbert, M. Guiral, S. Lecomte, M.T. Giudici-Orticoni, E. Lojou, Angew. Chem. Int. Ed. 51 (2012) 953-956.

[100] W. Lubitz, H. Ogata, O. Rüdiger, E. Reijerse, Chem. Rev. 114 (2014) $4081-4148$.

[101] A.F. Wait, A. Parkin, G.M. Morley, L. dos Santos, F.A. Armstrong, J. Phys Chem. C 114 (2010) 12003-12009.

[102] M.-E. Pandelia, V. Fourmond, P. Tron-Infossi, E. Lojou, P. Bertrand, C. Léger, M.-T. Giudici-Orticoni, W. Lubitz, J. Am. Chem. Soc. 132 (2010) 6991-7004

[103] K.A. Vincent, J.A. Cracknell, O. Lenz, I. Zebger, B. Friedrich, F.A. Armstrong, Proc. Natl. Acad. Sci. U. S. A. 102 (2005) 16951-16954.

[104] A. Ciaccafava, A. De Poulpiquet, V. Techer, M.T. Giudici-Orticoni, S. Tingry, C. Innocent, E. Lojou, Electrochem. Commun. 23 (2012) 25-28.

[105] S. Krishnan, F.A. Armstrong, Chem. Sci. 3 (2012) 1015-1023.

[106] L. Xu, F.A. Armstrong, Energy Environ. Sci. 6 (2013) 2166-2171.

[107] N. Plumeré, O. Rüdiger, A.A. Oughli, R. Williams, J. Vivekananthan, S. Pöller, W. Schuhmann, W. Lubitz, Nat. Chem. 6 (2014) 822-827.

[108] V. Fourmond, S. Stapf, H. Li, D. Buesen, J. Birrell, O. Rüdiger, W. Lubitz, W. Schuhmann, N. Plumeré, C. Léger, J. Am. Chem. Soc. 137 (2015) 5494-5505.

[109] A.A. Babadi, S. Bagheri, S. Bee, A. Hamid, Biosens. Bioelectron. 79 (2016) 850-860.

[110] M. Holzinger, A. Le Goff, S. Cosnier, Electrochim. Acta 82 (2012) 179-190

[111] M. Holzinger, R. Haddad, A. Le Goff, S. Cosnier, Carbon nanotube matrices for enzymatic glucose biofuel cells: shapes and growth, in: S.E. Lyshevski (Ed.), Dekker Encyclopedia of Nanoscience and Nanotechnology, 2016CRC Press, Taylor \& Francis Grouphttp://dx.doi.org/10.1081/EENN1083-120054011 (in press)

[112] M. Bourourou, M. Holzinger, K. Elouarzaki, A. Le Goff, F. Bossard, C. Rossignol, E. Djurado, V. Martin, D. Curtil, D. Chaussy, A. Maaref, S. Cosnier, Chem. Commun. 51 (2015) 14574-14577.

[113] A.J. Bandodkar, I. Jeerapan, J.-M. You, R. Nuñez-Flores, J. Wang, Nano Lett. 16 (2016) 721-727.

[114] M. Bourourou, K. Elouarzaki, M. Holzinger, C. Agnes, A. Le Goff, N. Reverdy-Bruas, D. Chaussy, M. Party, A. Maaref, S. Cosnier, Chem. Sci. 5 (2014) 2885-2888

[115] C.W. Narváez Villarrubia, C. Lau, G.P.M.K. Ciniciato, S.O. Garcia, S.S. Sibbett, D.N. Petsev, S. Babanova, G. Gupta, P. Atanassov, Electrochem. Commun. 45 (2014) 44- 47.

[116] D.N. Futaba, K. Hata, T. Yamada, T. Hiraoka, Y. Hayamizu, Y. Kakudate, O. Tanaike, H. Hatori, M. Yumura, S. Iijima, Nat. Mater. 5 (2006) 987-994.

[117] S.K. Ujjain, R. Bhatia, P. Ahuja, P. Attri, PLoS One 10 (2015) e0131475.

[118] M. Kizling, K. Stolarczyk, P. Tammela, Z. Wang, L. Nyholm, J. Golimowski, R. Bilewicz, Bioelectrochemistry (2016) http://dx.doi.org/10.1016/j. bioelechem.2016.1001.1004. in press, Accepted Manuscript.

[119] E. Katz, K. MacVittie, Energy Environ. Sci. 6 (2013) 2791-2803.

[120] L. Hussein, S. Rubenwolf, F. von Stetten, G. Urban, R. Zengerle, M. Krüger, S. Kerzenmacher, Biosens. Bioelectron. 26 (2011) 4133-4138.

[121] L. Hussein, G. Urban, M. Krüger, Phys. Chem. Chem. Phys. 13 (2011) $5831-5839$ 
[122] S. Cosnier, R. Haddad, D. Moatsou, R.K. O'Reilly, Carbon 93 (2015) $713-718$

[123] K. MacVittie, T. Conlon, E. Katz, Bioelectrochemistry 106 (2015) 28-33.

[124] Y. Holade, K. MacVittie, T. Conlon, N. Guz, K. Servat, T.W. Napporn, K.B. Kokoh, E. Katz, Electroanalysis 27 (2015) 276-280.

[125] S. Babanova, K. Artyushkova, Y. Ulyanova, S. Singhal, P. Atanassov, J. Power Sources 245 (2014) 389-397.

[126] G.P.M.K. Ciniciato, C. Lau, A. Cochrane, S.S. Sibbett, E.R. Gonzalez, P. Atanassov, Electrochim. Acta 82 (2012) 208-213.

[127] J.Y. Oh, S.J. Yang, J.Y. Park, T. Kim, K. Lee, Y.S. Kim, H.N. Han, C.R. Park, Nano Lett. 15 (2015) 190-197.

[128] S. Wang, R. Downes, C. Young, D. Haldane, A. Hao, R. Liang, B. Wang, C. Zhang, R. Maskell, Adv. Eng. Mater. 17 (2015) 1442-1453.

[129] M. Naebe, T. Lin, X. Wang, Carbon nanotubes reinforced electrospun polymer nanofibres, in: A. Kumar (Ed.), Nanotechnology and Nanomaterials "Nanofibers", 2010InTech.

[130] J. Steinmetz, M. Glerup, M. Paillet, P. Bernier, M. Holzinger, Carbon 43 (2005) 2397-2429.

[131] K. Wei, H.-R. Kim, B.-S. Kim, I.-S. Kim, Electrospun metallic nanofibers fabricated by electrospinning and metallization, in: D.T. Lin (Ed.), Nanofibers
- Production, Properties and Functional Applications, 2011InTech, pp. $117-134$.

[132] L. Zhang, A. Aboagye, A. Kelkar, C. Lai, H. Fong, J. Mater. Sci. 49 (2014) 463-480.

[133] S.N. Arshad, M. Naraghi, I. Chasiotis, Carbon 49 (2011) 1710-1719.

[134] D.P. Bahl, R.B. Mathur, T.L. Dhami, Mater. Sci. Eng. 73 (1985) 105-112.

[135] P. Heikkila, A. Harlin, eXPRESS Polym. Lett. 3 (2009) 437-445.

[136] W. Zheng, J.Y. Ma, F. Guo, J. Li, H.M. Zhou, X.X. Xu, L. Li, Y.F. Zheng, Bio-Med. Mater. Eng. 24 (2014) 229-235.

[137] M.D. Lima, S. Fang, X. Lepró, C. Lewis, R. Ovalle-Robles, J. CarreteroGonzález, E. Castillo-Martínez, M.E. Kozlov, J. Oh, N. Rawat, C.S. Haines, M.H. Haque, V. Aare, S. Stoughton, A.A. Zakhidov, R.H. Baughman, Science 331 (2011) 51-55.

[138] S. Rubenwolf, S. Sané, L. Hussein, J. Kestel, F. von Stetten, G. Urban, M. Krueger, R. Zengerle, S. Kerzenmacher, Appl. Microbiol. Biotechnol. 96 (2012) 841-849.

[139] Y. Holade, K. MacVittie, T. Conlon, N. Guz, K. Servat, T.W. Napporn, K.B. Kokoh, E. Katz, Electroanalysis 26 (2014) 2445-2457. 